\title{
Tinjauan Kasus Berbasis Bukti \\ Perbandingan Kriteria ACR-1997 dan SLICC-2012 dalam Diagnosis Lupus Eritematosus Sistemik pada Anak
}

Dwi Lestari Pramesti, Dina Muktiarti

Departemen Ilmu Kesehatan Anak Fakultas Kedokteran Universitas Indonesia/RSUPN Cipto Mangunkusumo, Jakarta

Latar belakang. Lupus eritematosus sistemik merupakan penyakit autoimun sistemik pada jaringan ikat yang bersifat kronik dan progresif, terutama pada anak. Hingga saat ini belum ada diagnosis baku emas, sehingga untuk menegakkan diagnosis dapat menggunakan kriteria The American College of Rheumatology (ACR) tahun 1997 atau The Systemic Lupus International Collaborating Clinics (SLICC) tahun 2012. Tujuan. Mengumpulkan bukti ilmiah perbandingan penggunaan kriteria ACR-1997 dan SLICC-2012 dalam diagnosis lupus eritematosus sistemik pada anak.

Metode. Penelusuran literatur secara sistematis secara daring melalui database Pubmed dan Cochrane. Analisis dilakukan menggunakan Review Manager dan model hierarchical summary receiver operating characteristic (HSROC) pada studi meta-analisis. Kualitas studi dinilai dengan QUADAS-2.

Hasil. Satu artikel telaah sistematis dan meta-analisis dan satu artikel studi longitudinal dilakukan telaah kritis. Kualitas kedua studi dinilai baik. Studi oleh Hartman dkk menunjukkan kriteria ACR-1997 lebih dianjurkan sebagai kriteria klasifikasi LES pada anak karena lebih spesifik (94,1\% vs $82 \%$ ) dan menghindari terjadinya positif palsu. Studi kedua oleh Lythgoe dkk menunjukkan SLICC-2012 lebih sensitif $(92,9 \%$ vs $84,1 \%)$ dan secara lebih dini mengklasifikasi pasien anak dengan LES.

Kesimpulan. Kriteria SLICC-2012 memiliki sensitivitas yang lebih tinggi dalam klasifikasi LES pada anak tetapi memiliki spesifisitas yang lebih rendah dibandingkan ACR-1997. Namun, SLICC-2012 dapat mengklasifikasi LES lebih dini secara signifikan dibandingkan ACR1997. Sari Pediatri 2021;22(6):386-93

Kata kunci: lupus eritematosus sistemik, ACR-1997, SLICC-2012

\section{Evidence-based Case Report Comparison of ACR-1997 dan SLICC-2012 Criteria for Systemic Lupus Erythematosus Diagnosis in Children:}

Dwi Lestari Pramesti, Dina Muktiarti

Background. Systemic lupus erythematosus is a chronic and progressive systemic autoimmune disease of connective tissue, especially in children. Until now there has been no gold standard diagnosis, therefore The American College of Rheumatology (ACR) in 1997 or The Systemic Lupus International Collaborating Clinics (SLICC) in 2012 criteria usually used.

Objective. To evaluate scientific evidence comparing the use of ACR-1997 and SLICC-2012 criteria in diagnosing systemic lupus erythematosus in children.

Methods. A systematic online literature search using Pubmed and Cochrane databases. Analyzes were performed using the Review Manager and the Hierarchical Summary Receiver Operating Characteristic (HSROC) model in the meta-analysis study. Study quality was assessed by QUADAS-2.

Results. One systematic review and meta-analysis article and one longitudinal study article were included in critical appraisal. Both studies had good quality. The first study by Hartman et al. showed that the ACR-1997 criteria were more recommended as the LES classification criteria in children because it was more specific ( $94.1 \%$ vs $82 \%$ ) and avoided the false positives rate. The other study by Lythgoe et al. showed that SLICC-2012 was more sensitive (92.9\% vs $84.1 \%)$ and earlier classified pediatric patients with LES.

Conclusion. The SLICC-2012 criteria have a higher sensitivity in classifying LES in children but have lower specificity than the ACR-1997. However, SLICC-2012 was able to classify LES significantly earlier than ACR-1997. Sari Pediatri 2021;22(6):386-93

Keywords: systemic lupus erythematosus, ACR-1997, SLICC-2012

Alamat korespondensi: Dwi Lestari Pramesti. Departemen Ilmu Kesehatan Anak, Fakultas Kedokteran Universitas Indonesia/RSUPN Cipto Mangunkusumo, Jakarta 10430. Email: m.ariotedjo@gmail.com 
Dwi Lestari Pramesti dkk: Perbandingan kriteria ACR-1997 dan SLICC-2012 dalam diagnosis lupus eritematosus sistemik

$\mathrm{L}$ upus eritematosus sistemik (LES) adalah penyakit autoimun sistemik pada jaringan ikat yang bersifat kronik dan adanya autoantibodi terhadap antigen di nukleus. Diagnosis baku emas LES hingga saat ini belum tersedia sehingga LES sering sulit dan terlambat ditegakkan. Selain itu, LES merupakan penyakit yang dapat menyebabkan kegagalan organ secara progresif, terutama pada pasien anak, sehingga LES harus diidentifikasi secara cepat dan akurat. ${ }^{1}$

The American College of Rheumatology (ACR) memiliki satu kriteria klasifikasi yang diinisiasi pada tahun 1982 dan telah diperbarui pada tahun 1997. Walaupun tidak pernah divalidasi, kriteria ACR-1997 sudah banyak digunakan. Terdapat kekhawatiran bahwa ACR-1997 dapat membatasi diagnosis LES terutama pada pasien anak yang perjalanan penyakitnya masih dini atau pun pada pasien nefritis lupus karena kriteria ACR-1997 tidak mengklasifikasi nefritis lupus terisolir sebagai LES, sedangkan nefritis lupus sering kali merupakan manifestasi utama pada pasien anak dengan LES. ${ }^{1,2}$

The Systemic Lupus International Collaborating Clinics (SLICC) melakukan revisi kriteria klasifikasi LES pada dewasa untuk memperbaiki kekurangan pada kriteria ACR-1997. ${ }^{3}$ SLICC-2012 mengklasifikasi pasien nefritis lupus dengan hasil biopsi ginjal yang sesuai, disertai pemeriksaan antinuclear antibodies (ANA) atau anti-double stranded DNA (anti-dsDNA) yang positif sebagai LES tanpa memerlukan kriteria lainnya; perluasan definisi lupus kutaneus dan neurologis; tambahan kriteria baru seperti alopesia dan komplemen yang rendah; disagregasi dari kriteria hematologis dan imunologis ACR-1997. 'Kriteria SLICC-2012 pada pasien dewasa telah terbukti memiliki performa yang lebih baik dalam mengklasifikasi pasien LES dibandingkan kriteria ACR-1997. ${ }^{4}$ Laporan kasus berbasis bukti ini bertujuan membandingkan sensitivitas dan spesifisitas kriteria ACR-1997 dan SLICC-2012 sebagai kriteria klasifikasi LES serta peran kedua kriteria tersebut dalam menegakkan diagnosis LES secara dini pada anak.

\section{Kasus}

Anak perempuan, usia 15 tahun, datang ke IGD dengan keluhan pucat dan demam yang naik-turun sejak 5 hari SMRS. Tidak ada riwayat perdarahan atau riwayat transfusi darah berulang sebelumnya. Riwayat demam lama, pucat, kemerahan pada pipi, rambut rontok, atau nyeri sendi disangkal. Pasien sudah menstruasi sejak usia 12 tahun dan teratur hingga saat ini. Berat badan pasien menurun sejak satu minggu. Pemeriksaan uji Coomb's direk pasien menunjukkan hasil inkompatibel mayor dan minor. Riwayat penyakit autoimun, keganasan, gangguan darah pada keluarga disangkal.

Pada pemeriksaan fisis pasien tampak pucat, tanda vital dalam batas normal, konjungtiva pucat, pemeriksaan lainnya dalam batas normal. Pemeriksaan antropometri menunjukkan status gizi baik dan perawakan normal. Pemeriksaan penunjang awal menunjukkan anemia normositik normokrom, titer ANA > 1/1000 dengan pola homogen, dan anti ds-DNA 806,2 IU/mL.

Pada awal perawatan, pasien didiagnosis dengan anemia hemolitik autoimun dan mendapat terapi steroid, serta transfusi darah berulang dengan washed erythrocytes. Tiga minggu kemudian, pasien dievaluasi kembali ke arah LES. Berat badan pasien terus menurun dan demam hilang timbul, tetapi tidak didapatkan ruam malar, lesi diskoid, fotosensitivitas, ulkus mukosa, artritis, atau kejang. Pemeriksaan ekokardiografi menunjukkan anatomi dan fungsi jantung dalam batas normal. Pemeriksaan darah pasien menunjukkan $\mathrm{Hb}$ $12,1 \mathrm{~g} / \mathrm{dL}$, Ht 35,2\%, leukosit 6.300/ $\mu \mathrm{L}$, trombosit $345.000 / \mu \mathrm{L}$, LED $75 \mathrm{~mm}$, SGOT $10 \mathrm{U} / \mathrm{L}$, SGPT 16 $\mathrm{U} / \mathrm{L}$, ureum $27 \mathrm{mg} / \mathrm{dL}$, kreatinin 0,5 mg/dL, C3 33,8 $\mathrm{mg} / \mathrm{dL}$, dan C4 2,37 mg/dL. Pasien tidak memenuhi klasifikasi LES berdasarkan ACR-1997 karena hanya tiga dari sebelas komponen kriteria yang sesuai, yaitu komponen gangguan hematologis, imunologis, dan ANA. Namun, pasien memenuhi kriteria SLICC-2012 yaitu satu komponen klinis (anemia hemolitik) dan tiga komponen imunologis (ANA, anti-dsDNA, dan komplemen yang rendah (C3 dan C4)).

\section{Pertanyaan klinis}

Apakah pasien anak yang memenuhi kriteria klasifikasi SLICC-2012 tetapi tidak memenuhi kriteria ACR-1997 dapat didiagnosis sebagai lupus eritematosus sistemik? Populasi (P) : Pasien anak dengan gejala klinis lupus eritematosus sistemik

Intervensi (I) : SLICC-2012 
$\begin{array}{ll}\text { Pembanding }(\mathrm{C}) & \text { : ACR-1997 } \\ \text { Hasil }(\mathrm{O}) & \text { : diagnosis LES }\end{array}$

\section{Metode pencarian literatur}

Pertanyaan klinis di atas dijawab dengan pencarian literatur melalui Pubmed dan Cochrane dengan kata kunci "pediatric" AND "systemic lupus erythematosus" AND " $A C R$ " AND "SLICC" AND "diagnosis". Setelah artikel didapatkan, dilakukan seleksi dengan kriteria inklusi, yaitu artikel dalam bahasa Inggris, publikasi kurang dari lima tahun, studi observasional, penelitian klinis, telaah sistematik, atau meta-analisis, serta kriteria eksklusi yaitu artikel ganda dan tanpa full text (Gambar 1). Setelah melalui proses seleksi dengan membaca judul dan abstrak, dua artikel yang relevan dipilih dan dilakukan penilaian secara kritis dengan alat penilaian dari laman Oxford Centre for Evidence-based Medicine (www.cebm.net) untuk jenis atau desain studi yang sesuai.

\section{Hasil penelusuran literatur}

Setelah penelusuran literatur secara sistematis, didapatkan dua buah artikel yang relevan terhadap pertanyaan klinis ditemukan (Tabel 1). Penelitian pertama merupakan telaah sistematis dan meta-analisis oleh Hartman dkk. ${ }^{2}$ terhadap 9 studi kohort pada dewasa dan 4 studi kohort pada anak pada tahun 20122016 yang membandingkan sensitivitas dan spesifisitas kriteria klasifikasi ACR-1997 dan SLICC-2012 (level of evidence: $2 \mathrm{a}) .{ }^{5}$ Penelitian kedua adalah studi longitudinal (level of evidence: $2 \mathrm{~b}$ ) pada studi kohort UK JSLE. ${ }^{1}$ Kedua literatur tersebut kemudian dilakukan telaah kritis (Tabel 1).

Analisis data menggunakan Review Manager 5.3 untuk menghitung sensitivitas dan spesifisitas serta confident interval pada setiap studi. Untuk mengestimasi sensitivitas dan spesifisitas melalui meta-analisis secara keseluruhan, hanya studi yang mengaplikasikan SLICC-2012 dan ACR-1997 sebagai indext tests, dan diagnosis klinis sebagai referensi standar yang dilakukan perhitungan. Meta-analisis dilakukan dengan model HSROC dan Bivariat. Kualitas dari masing-masing studi dinilai menggunakan formulir QUADAS-2.

Untuk menentukan apakah SLICC-2012 mengklasifikasi pasien lebih dini dari ACR-1997, perbandingan terhadap pasien anak dan dewasa dengan durasi penyakit LES $<5$ tahun dilakukan. Sensitivitas dan spesifisitas dari setiap komponen SLICC-2012 dan ACR-1997 juga dibandingkan secara terpisah. Untuk menganalisis perbedaan ACR-1997 dan SLICC-2012 dalam memengaruhi klasifikasi populasi LES, peneliti membandingkan karakteristik pasien yang memenuhi kriteria ACR-1997, tetapi tidak memenuhi kriteria SLICC-2012, dan sebaliknya. ${ }^{2}$

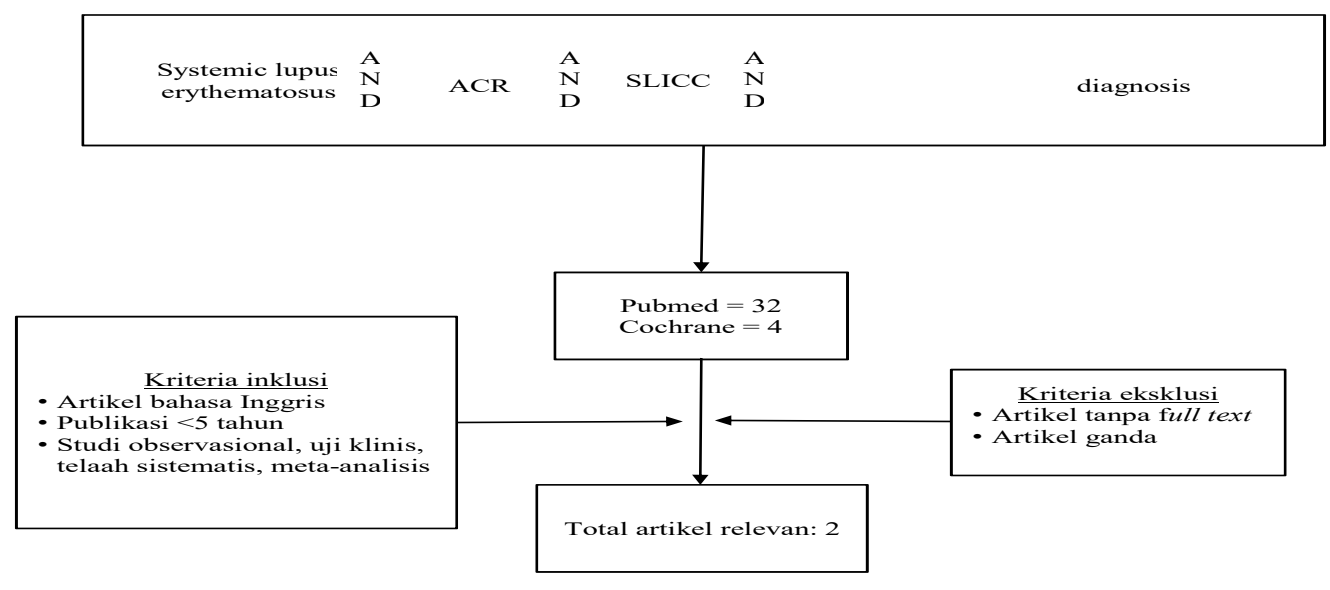

Gambar 1. Diagram alur pemilihan literatur 
Tabel 1. Telaah kritis

\begin{tabular}{|c|c|c|}
\hline Artikel (tahun) & Hartmann dkk. ${ }^{2}(2018)$ & Lythgoe dkk. $^{1}$ (2017) \\
\hline Desain penelitian & Telaah sistematis dan meta-analisis & Longitudinal \\
\hline Level of evidence & $2 \mathrm{a}$ & $2 \mathrm{~b}$ \\
\hline Validity & $\begin{array}{l}\text { PICO } \\
\text { Pertanyaan klinis tergambar pada abstrak dan akhir } \\
\text { paragraf pendahuluan, yaitu untuk mengevaluasi } \\
\text { performa kriteria klasifikasi SLICC-2012 } \\
\text { dibandingkan dengan ACR-1997 pada pasien anak } \\
\text { dan dewasa dengan lupus eritematosus sistemik. } \\
\text { Missed relevant studies } \\
\text { Penelusuran dilakukan melalui database PubMed } \\
\text { dan Embase, serta menghubungi peneliti terkait } \\
\text { untuk data tambahan dengan kata kunci "SLE" } \\
\text { atau "systemic lupus erythematosus" atau "lupus" } \\
\text { dan "criteria" atau "clasification", dan "SLICC" atau } \\
\text { "Systemic Lupus International Collaborating Clinics" } \\
\text { serta waktu publikasi pada tahun 2012. Peneliti } \\
\text { menyebutkan abstrak dan full text yang didapat, } \\
\text { artikel yang dieksklusi dan alasannya. } \\
\text { Kriteria inklusi } \\
\text { Semua studi observasional dan studi klinis pada } \\
\text { pasien lupus eritematosus sistemik dengan diagnosis } \\
\text { klinik LES, kriteria klasifikasi SLICC-2012 dan } \\
\text { ACR-1997. } \\
\text { Validitas dari studi yang dipilih } \\
\text { Pada bagian metodologi disebutkan kemungkinan } \\
\text { bias yang terjadi pada jenis studi yang berbeda dan } \\
\text { analisis kualitas yang dilakukan. Hasil tiap studi } \\
\text { disajikan dalam tabel.- } \\
\text { Hasil serupa antar studi } \\
\text { Homogen } \\
\text { Kesimpulan: sahih }\end{array}$ & $\begin{array}{l}\text { Apakah uji diagnostik dilakukan pada spektrum } \\
\text { pasien yang representatif? } \\
\text { Ya, subjek yang diikutsertakan dalam studi } \\
\text { merupakan pasien anak dengan lupus } \\
\text { eritematosus sistemik yang diagnosisnya sudah } \\
\text { tegak berdasarkan kriteria klasifikasi ACR-1997 } \\
\text { maupun pasien dengan gejala LES awal dan } \\
\text { termasuk dalah studi kohort UK JSLE. } \\
\text { Apakah baku emas tetap dilakukan tanpa } \\
\text { memandang hasil indeks? } \\
\text { Alternatif baku emas berupa pemantauan } \\
\text { para pasien selama minimal satu tahun pasca } \\
\text { diagnosis. } \\
\text { Apakah dilakukan pengukuran yang } \\
\text { independen atau tersamar antara uji indeks } \\
\text { dengan baku emas? } \\
\text { Tidak dilakukan pengukuran independen atau } \\
\text { tersamar. }\end{array}$ \\
\hline Importance & $\begin{array}{l}\text { Luaran sensitivitas dan spesifisitas SLICC-2012 } \\
\text { dibandingkan ACR-1997: } \\
\text { Kesimpulan: Kriteria ACR-1997 lebih dianjurkan } \\
\text { sebagai kriteria klasifikasi LES pada anak karena lebih } \\
\text { spesifik dan menghindari terjadinya positif palsu. }\end{array}$ & $\begin{array}{l}\text { SLICC-2012 } \\
\text { Sensitivitas: } 92,9 \% \\
\text { ACR-1997 } \\
\text { Sensitivitas: } 84,1 \% \\
\text { Spesifisitas, negative predictive value, dan positive } \\
\text { predictive value tidak dapat dinilai karena } \\
\text { seluruh pasien pada studi ini adalah pasien LES } \\
\text { Kesimpulan: SLICC-2012 lebih sensitif dan } \\
\text { secara lebih dini mengklasifikasi pasien anak } \\
\text { dengan LES. }\end{array}$ \\
\hline Applicability & $\begin{array}{l}\text { Apakah sama dengan kondisi pasien? Ya } \\
\text { Apakah intervensi bisa dilakukan di tempat saya } \\
\text { bekerja? Ya } \\
\text { Apakah keuntungan lebih besar dibandingkan } \\
\text { kerugian? Ya } \\
\text { Kesimpulan: dapat diterapkan }\end{array}$ & $\begin{array}{l}\text { Apakah sama dengan kondisi pasien? } \\
\text { Ya } \\
\text { Apakah intervensi dapat dilakukan di tempat } \\
\text { saya bekerja? } \\
\text { Ya } \\
\text { Apakah keuntungan lebih besar dibandingkan } \\
\text { kerugian? } \\
\text { Ya } \\
\text { Kesimpulan: Dapat diaplikasikan }\end{array}$ \\
\hline
\end{tabular}


Dwi Lestari Pramesti dkk: Perbandingan kriteria ACR-1997 dan SLICC-2012 dalam diagnosis lupus eritematosus sistemik

Tabel 2. Perbandingan kriteria klasifikasi ACR-1997 dan SLICC-2012²

\begin{tabular}{|c|c|}
\hline ACR-1997 & SLICC-2012 \\
\hline \multirow[t]{2}{*}{4 dari 11 kriteria } & $\begin{array}{l}4 \text { dari } 11 \text { kriteria termasuk } 11 \text { kriteria klinis dan } 1 \text { dari } 6 \text { kriteria } \\
\text { imunologis } \\
\text { ATAU nefritis lupus yang terbukti dari hasil biopsi ginjal dengan ANA atau } \\
\text { antibodi anti-dsDNA yang positif }\end{array}$ \\
\hline & Kriteria klinis \\
\hline $\begin{array}{l}\text { 1. Ruam malar } \\
\text { Eritema berbatas tegas dengan permukaan yang rata atau } \\
\text { menebal, menyeberangi hidung, namun jarang mengenai } \\
\text { lipatan nasolabial. }\end{array}$ & $\begin{array}{l}\text { 1. Lupus kutaneus akut, termasuk: } \\
\text { Ruam malar lupus, lupus bulosa, varian nekrolisis, epidermal toksik, } \\
\text { ruam makulopapular lupus, ruam fotosensitivitas lupus, tanpa adanya } \\
\text { dermatomiositis. } \\
\text { ATAU lupus kutaneous subakut (nonindurated psoriaform dan/ atau lesi } \\
\text { polisiklik anular yang sembuh tanpa jaringan parut, meskipun dapat } \\
\text { terdapat dispigmentasi pasca inflamasi atau teleangiektasia) }\end{array}$ \\
\hline $\begin{array}{l}\text { 2. Ruam diskoid } \\
\text { Plak eritematosa dengan skuama keratotik dan sumbatan } \\
\text { folikel. Skar atrofi dapat terjadi pada lesi yang lebih lama. }\end{array}$ & $\begin{array}{l}\text { 2. Lupus kutaneus kronik, termasuk: } \\
\text { Ruam diskoid klasik, lokal (di atas leher), generalisata (di atas dan di bawah } \\
\text { leher), hypertrophic (verrucous) lupus, lupus panniculitis (profundus), lupus } \\
\text { mukosal, lupus eritematosus tumidus, Chillblains lupus, discoid lupus/ } \\
\text { lichen planus overlap. }\end{array}$ \\
\hline
\end{tabular}

3. Foto sensitivitas

Ruam kulit sebagai reaksi paparan terhadap sinar matahari, berdasarkan anamnesis pasien atau pemeriksaan fisis.

4. Ulkus oral

Ulkus oral atau pun nasofaringeal, biasanya tidak nyeri.

3. Ulkus oral

Palatum, bukal, lidah ATAU ulkus nasal tanpa disertai penyebab lain seperti vaskulitis, penyakit Behcet, infeksi, inflammatory bowel disease, artritis reaktif, dan makanan asam.

4. Alopesia tanpa jaringan parut (penipisan rambut difus atau rambut rapuh dengan helai rambut yang patah yang jelas terlihat), tanpa adanya penyebab lain seperti alopesia aerata, obat, defisiensi besi, dan alopesia androgenik.

5. Artritis non erosif

Artritis non-erosif yang melibatkan dua atau lebih sendi perifer dengan ciri-ciri nyeri tekan, pembengkakan atau efusi sendi.

6. Pleuritis atau perikarditis

Pleuritis (keluhan riwayat pleuritic pain atau rub yang

terdengar pada pemeriksaan fisis atau bukti adanya efusi pleura)

ATAU

Perikarditis (dibuktikan dengan pemeriksaan

elektrokardiogram atau ditemukannya friction rub atau

bukti adanya efusi perikardium).

\section{Kelainan ginjal}

Proteinuria persisten $>0.5$ gram/ hari atau $>+3$ bila tidak menggunakan pemeriksaan kuantitatif

ATAU

Silinder sel eritrosit, hemoglobin, tubular, granular, atau campuran.

8. Kelainan neurologi

Kejang yang bukan disebabkan oleh gangguan metabolik maupun efek samping obat ATAU

Psikosis yang bukan disebabkan oleh gangguan metabolik maupun efek samping obat.

\section{Sinovitis}

Peradangan yang melibatkan 2 atau lebih sendi dengan karakteristik pembengkakan atau efusi ATAU nyeri pada 2 atau lebih sendi dan keluhan morning stiffness yang berlangsung setidaknya 30 menit.

\section{Serositis}

Pleuritis khas terjadi lebih dari satu hari

ATAU efusi pleura ATAU pleural rub

Nyeri perikardial khas (nyeri yang berkurang dengan duduk condong ke arah depan) terjadi lebih dari satu hari ATAU efusi perikard ATAU pericardial rub

ATAU perikarditis dari elektrokardiografi (tanpa ada penyebab lain seperti infeksi, uremia, dan perikarditis Dressler's).

\section{Renal}

Rasio kreatinin albumin urine (atau protein tampung 24 jam) merepresentasikan protein $500 \mathrm{mg} / 24$ jam

ATAU silinder eritrosit.

\section{Neurologi}

Kejang, psikosis, mononeuritis multipleks

(Tanpa adanya penyebab lain seperti vaskulitis primer, infeksi, dan diabetes melitus).

Perubahan kesadaran akut (Tanpa ada penyebab lain seperti toksin/ metabolik, uremia, obat). 
Dwi Lestari Pramesti dkk: Perbandingan kriteria ACR-1997 dan SLICC-2012 dalam diagnosis lupus eritematosus sistemik

\begin{tabular}{|c|c|}
\hline ACR-1997 & SLICC-2012 \\
\hline \multirow[t]{4}{*}{$\begin{array}{l}\text { 9. Kelainan hematologi } \\
\text { Anemia hemolitik dengan retikulosis ATAU leukopenia } \\
(<4.000 / \mathrm{mm} 3 \text { pada dua atau lebih pemeriksaan) } \\
\text { ATAU limfopenia }(<1.500 / \mathrm{mm} 3 \text { pada dua atau lebih } \\
\text { pemeriksaan) ATAU trombositopenia }(<100.000 / \mathrm{mm} 3 \\
\text { yang tidak berkaitan dengan efek samping obat). }\end{array}$} & 9. Anemia hemolitik \\
\hline & $\begin{array}{l}\text { 10. Leukopenia }(<4.000 / \mathrm{mm} 3 \text { paling tidak pada satu pemeriksaan) tanpa } \\
\text { adanya penyebab lain seperti Sindrom Felty's, obat-obatan, dan hipertensi } \\
\text { portal. } \\
\text { ATAU limfopenia }(<1.000 / \mathrm{mm} 3 \text { paling tidak pada satu pemeriksaan) tanpa } \\
\text { adanya penyebab lain seperti kortikosteroid, obat-obatan, dan infeksi. }\end{array}$ \\
\hline & $\begin{array}{l}\text { 11. Trombositopenia }(<100.000 / \mathrm{mm} 3) \\
\text { Tanpa adanya penyebab lain seperti obat-obatan, hipertensi portal, dan } \\
\text { trombositopenia trombosis purpura. }\end{array}$ \\
\hline & Kriteria imunologis \\
\hline $\begin{array}{l}\text { 10. Kelainan imunologis } \\
\text { Anti-dsDNA: peningkatan abnormal titer antibodi dsDNA } \\
\text { ATAU Anti-Sm: terdeteksi antibodi antiSm, } \\
\text { ATAU antibodi antifosfolipid: (1) peningkatan abnormal } \\
\text { titer antibodi antikardiolipin IgG atau IgM; (2) hasil positif } \\
\text { untuk pemeriksaan lupus antikoagulan menggunakan } \\
\text { metode standar; atau (3) hasil positif palsu untuk } \\
\text { pemeriksaan serologi sifilis dalam jangka waktu } 6 \text { bulan } \\
\text { terakhir dan dikonfirmasi dengan pemeriksaan Treponema } \\
\text { pallidum immobilization atau fluorescent treponemal } \\
\text { antibody absorption. }\end{array}$ & 1. ANA, peningkatan titer ANA di atas nilai normal. \\
\hline \multirow[t]{5}{*}{$\begin{array}{l}\text { 11. Antibodi antinuklear } \\
\text { Peningkatan abnormal titer antibodi antinuklear } \\
\text { menggunakan pemeriksaan imunofluorosen atau } \\
\text { pemeriksaan lain yang setara, pada titik waktu kapanpun, } \\
\text { tanpa pengguaan obat yang terkait "drug-induced lupus". }\end{array}$} & $\begin{array}{l}\text { 2. Anti-dsDNA, peningkatan titer anti-dsDNA di atas nilai normal (atau } 2 \\
\text { kali lipat di atas nilai referensi apabila menggunakan metode ELISA. }\end{array}$ \\
\hline & 3. Anti-Sm, terdeteksinya antibodi terhadap antigen nuklear SM. \\
\hline & $\begin{array}{l}\text { 4. Antibodi antifosfolipid positif, yaitu: hasil positif pada pemeriksaan } \\
\text { lupus antikoagulan, hasil positif palsu pada pemeriksaan rapid plasma } \\
\text { reagen, hasil titer medium atau tinggi pada pemeriksaan kadar antibodi } \\
\text { antikardiolipin (IgA, IgG, IgM), hasil positif pada pemeriksaan antibodi } \\
\text { anti- } \beta 2 \text {-glikoprotein I (IgA, IgG, IgM). }\end{array}$ \\
\hline & 5. Penurunan komplemen $(\mathrm{C} 3, \mathrm{C} 4, \mathrm{CH} 50)$ \\
\hline & $\begin{array}{l}\text { 6. Pemeriksaan direct Coomb's test positif (tidak dihitung apabila terdapat } \\
\text { hemolitik anemia) }\end{array}$ \\
\hline
\end{tabular}

\section{Pembahasan}

Kedua artikel yang ditelaah menyatakan SLICC-2012 memiliki sensitivitas yang lebih tinggi dibandingkan ACR-1997 dalam klasifikasi LES pada anak. ${ }^{1,2}$ Kriteria SLICC-2012 memiliki sensitivitas yang lebih unggul akibat modifikasi dan tambahan unsur-unsur kriteria baru, seperti penegakan kriteria LES hanya berdasarkan biopsi ginjal dengan hasil ANA dan anti-dsDNA yang positif, alopesia, komplemen yang rendah, serta hasil tes Coomb direk yang positif tanpa perlu disertai anemia hemolitik pada pasien. Namun, Hartman dkk menyimpulkan bahwa ACR-1997 secara signifikan memiliki spesifisitas yang lebih tinggi sebagai kriteria klasifikasi LES pada anak (Tabel 2). Oleh karena itu, artikel Hartman dkk lebih merekomendasikan ACR1997 sebagai kriteria klasifikasi LES pada anak untuk keperluan diagnosis. Namun, terdapat beberapa aspek yang perlu dipertimbangkan, yaitu kemampuan kedua kriteria dalam mengidentifikasi LES secara dini serta spesifisitas komponen kriteria yang tinggi sehingga dapat membantu untuk melakukan rule in pasien LES. 
Lupus eritematosus sistemik pada anak bersifat progresif dengan manifestasi klinis yang lebih berat sehingga diagnosis perlu ditegakkan secara dini. Berdasarkan kedua artikel, kemampuan SLICC-2012 dalam melakukan klasifikasi LES lebih cepat secara bermakna. ${ }^{1,2}$ Berdasarkan artikel kedua, waktu rerata klasifikasi dengan kriteria ACR-1997 dan SLICC-2012 adalah 254 hari dan 38 hari secara berturut-turut, yang berbeda secara bermakna. Bahkan, studi Pons-Estel dkk ${ }^{3}$ menunjukkan bahwa kemampuan SLICC-2012 dalam mengklasifikasi LES lebih cepat dibandingkan penilaian klinis para ahli. Oleh karena itu, SLICC-2012 dapat membantu mengklasifikasi LES secara dini sehingga tata laksana dapat segera diberikan.

Berdasarkan artikel pertama, komplemen rendah, anti ds-DNA positif, dan lupus kutaneus akut memiliki spesifisitas tinggi dalam mengklasifikasi LES pada kriteria SLICC-2012. Penelitian Amezcua-Guerra ${ }^{4}$, Fonsesca ${ }^{6}$, Ighe ${ }^{9}$, Katsicas ${ }^{10}$, Petri ${ }^{11}$ menyatakan spesifitas komplemen rendah berturut-turut sebesar 99\%, 100\%, $85,5 \%$, dan $91 \%$. Sedangkan spesifisitas anti ds-DNA positif, yaitu 97\%, 100\%, 89,1\%, 100\%, dan 95,9\%. Spesifisitas lupus kutaneus akut 87\%, 66,5\%,100\%, dan $80,1 \% .^{2}$

Hasil kedua artikel sangat relevan dan bermanfaat sesuai PICO yang diajukan. Kedua artikel tersebut menunjukkan metode penelitian yang valid, hasil penting, serta dapat diterapkan pada populasi pasien LES anak di Indonesia. Namun, kedua kriteria tersebut bukanlah baku emas diagnostik dan penegakan diagnosis tetap berdasarkan penilaian klinis dari para ahli imunologi.

Pasien dalam ilustrasi kasus di atas memenuhi empat komponen kriteria SLICC-2012 (satu kriteria klinis dan tiga kriteria imunologis) tetapi hanya memenuhi tiga komponen ACR-1997. Pada pasien didapatkan nilai komplemen yang rendah. Komplemen rendah memiliki angka spesifisitas yang tinggi terhadap klasifikasi LES sehingga dapat membantu menegakkan diagnosis LES pada pasien ini. ${ }^{2}$ Atas dasar tersebut, pasien didiagnosis sebagai LES dan mendapat terapi sesuai LES.

\section{Kesimpulan}

Kriteria SLICC-2012 memiliki sensitivitas yang lebih tinggi dalam melakukan klasifikasi LES pada anak tetapi memiliki spesifisitas yang lebih rendah dibandingkan ACR-1997. Namun, SLICC-2012 dapat mengklasifikasi LES lebih dini secara signifikan dibandingkan ACR-1997. Komplemen rendah, anti-dsDNA positif, dan lupus kutaneus akut pada SLICC-2012 memiliki spesifisitas tinggi sehingga dapat membantu penegakkan diagnosis LES terutama pada pasien yang memenuhi kriteria SLICC-2012 tetapi tidak memenuhi kriteria ACR-1997.

\section{Saran}

Diperlukan penelitian untuk menentukan kriteria diagnostik LES yang lebih objektif dari penilaian klinis para ahli. Selain itu, penelitian terkait keuntungan dan kerugian tata laksana dini pada pasien dengan kecurigaan LES, tetapi diagnosis belum dapat ditegakkan perlu dilakukan sehingga dapat menjadi acuan para dokter dalam tata laksana pasien secara optimal dan progresivitas penyakit dapat dicegah.

\section{Daftar pustaka}

1. Lythgoe H, Morgan T, Heaf E, dkk. Evaluation of the ACR and SLICC classification criteria in juvenile-onset systemic lupus erythematosus: a longitudinal analysis. Lupus 2017;0:1-6.

2. Hartman EAR, van Royen-Kerkhof A, Jacobs JWG, Welsing PMJ, Fritsch-Stork RDE. Performance of the 2012 Systemic Lupus International Collaborating Clinics classification criteria versus the 1997 American College of Rheumatology classification criteria in adult and juvenile systemic lupus erythematosus. A systematic review and meta-analysis. Autoimun Rev 2018;17:316-22.

3. Pons-Estel GK, Wojdyla D, McGwin G, Magder LS, Petri MA, Pons-Estel BA. The American College Collaborating Clinics classification criteria for systemic lupus erythematosus in two multiethnic cohorts: a commentary. Lupus 2014;23:3-9.

4. Amezcua-Guerra LM, Higuera-Ortiz V, Arteaga-Garcia U, Gallegos-Nava S, Hubbe-Tena C. Performance of the 2012 Systemic Lupus International Collaborating Clinics and the 1997 American College of Rheumatology classification criteria for systemic lupus erythematosus in a real-life scenario. Arthritis Care Res. 2015;67:437-41.

5. Ines L, Silva C, Galindo M. Classification of systemic lupus erythematosus: Systemic Lupus International Collaborating Clinics versus American College of Rheumatology criteria. A comparative study of 2055 patients from a real-life, international systemic lupus erythematosus cohort. Arthritis Care Res 2015;67:1180-5.

6. Fonsesca AR, Gaspar-Elsas MIC, Land MGP, de Oliveira SKF. Comparison between three systems of classification criteria 
in juvenile systemic lupus erythematous. Rheumatology 2015;54:241-7.

7. Sag E, Tartaglione A, Batu ED, dkk. Performance of the new SLICC classification criteria in childhood systemic lupus erythematosus: a multicenter study. Clin Exp Rheumatol 2014;32:1-5.

8. Martinez MA, Chapparo R, Papasidero SB, dkk. Diagnostic value of the new classification criteria for systemic lupus erythematosus (SLE) developed by the systemic lupus international collaborating clinics (SLICC) group in an argentinian cohort of patients with SLE (abstract). Lupus
2013;22:62.

9. Ighe A, Dahlstrom O, Skogh T, Sjowall C. Application of the 2012 Systemic Lupus International Collaborating Clinics classification criteria to patients in a regional Swedish systemic lupus erythematosus register. Arthritis Res Ther 2015;17:1-8.

10. Katsicas MM, Borgia ER, Russo RA. Accuracy of Systemic Lupus International Collaborating Clinics classification criteria applied ot juvenile systemic lupus erythematosus patients (abstract). Ann Rheum Dis 2013;72:A741.

11. Petri M, Magder L. Classification criteria for systemic lupus erythematosus: a review. Lupus 2004;13:829-37. 